Gender and Sexuality in Latin America - Cases and Decisions 


\title{
IUS GENTIUM
}

COMPARATIVE PERSPECTIVES ON LAW AND JUSTICE

\author{
VOLUME 24
}

\section{Series Editors}

\author{
Mortimer N.S. Sellers \\ University of Baltimore \\ James Maxeiner \\ University of Baltimore
}

\section{Board of Editors}

Myroslava Antonovych, Kyiv-Mohyla Academy

Nadia de Araújo, Pontifical Catholic University of Rio de Janeiro Jasna Bakšic-Muftic, University of Sarajevo

David L. Carey Miller, University of Aberdeen

Loussia P. Musse Félix, University of Brasilia

Emanuel Gross, University of Haifa

James E. Hickey, Jr., Hofstra University

Jan Klabbers, University of Helsinki

Cláudia Lima Marques, Federal University of Rio Grande do Sul Aniceto Masferrer, University of Valencia

Eric Millard, West Paris University

Gabriël Moens, Murdoch University

Raul C. Pangalangan, University of the Philippines

Ricardo Leite Pinto, Lusíada University of Lisbon

Mizanur Rahman, University of Dhaka

Keita Sato, Chuo University

Poonam Saxena, University of Delhi

Gerry Simpson, London School of Economics

Eduard Somers, University of Ghent

Xinqiang Sun, Shandong University

Tadeusz Tomaszewski, Warsaw University

Jaap de Zwaan, Erasmus University Rotterdam

For further volumes:

http://www.springer.com/series/7888 
Cristina Motta • Macarena Sáez

Editors

Gender and Sexuality

in Latin America - Cases

and Decisions

望 Springer 


\author{
Editors \\ Cristina Motta \\ Consultant on Sexual Rights \\ Buenos Aires, Argentina
}

\author{
Macarena Sáez \\ Washington College of Law \\ American University \\ Washington, DC, USA
}

Previously published by SIGLO DEL HOMBRE EDITORES, 2008, TITLE OF VOLUME I: LA MIRADA DE LOS JUECES: GENERO EN LA JURISPRUDENCIA LATINOAMERICANA; TITLE OF VOLUME II: LA MIRADA DE LOS JUECES: SEXUALIDADES DIVERSAS EN LA JURISPRUDENCIA LATINOAMERICANA

\author{
ISBN 978-94-007-6198-8 \\ ISBN 978-94-007-6199-5 (eBook) \\ DOI 10.1007/978-94-007-6199-5 \\ Springer Dordrecht Heidelberg New York London
}

Library of Congress Control Number: 2013937994

C S Springer Science+Business Media Dordrecht 2013

This work is subject to copyright. All rights are reserved by the Publisher, whether the whole or part of the material is concerned, specifically the rights of translation, reprinting, reuse of illustrations, recitation, broadcasting, reproduction on microfilms or in any other physical way, and transmission or information storage and retrieval, electronic adaptation, computer software, or by similar or dissimilar methodology now known or hereafter developed. Exempted from this legal reservation are brief excerpts in connection with reviews or scholarly analysis or material supplied specifically for the purpose of being entered and executed on a computer system, for exclusive use by the purchaser of the work. Duplication of this publication or parts thereof is permitted only under the provisions of the Copyright Law of the Publisher's location, in its current version, and permission for use must always be obtained from Springer. Permissions for use may be obtained through RightsLink at the Copyright Clearance Center. Violations are liable to prosecution under the respective Copyright Law.

The use of general descriptive names, registered names, trademarks, service marks, etc. in this publication does not imply, even in the absence of a specific statement, that such names are exempt from the relevant protective laws and regulations and therefore free for general use.

While the advice and information in this book are believed to be true and accurate at the date of publication, neither the authors nor the editors nor the publisher can accept any legal responsibility for any errors or omissions that may be made. The publisher makes no warranty, express or implied, with respect to the material contained herein.

Printed on acid-free paper

Springer is part of Springer Science+Business Media (www.springer.com) 


\section{Foreword}

Gender and Sexuality in Latin America: Cases and Decisions, edited by Cristina Motta and Macarena Sáez, is a long over-due book. It advances understanding of legal developments concerning women and LGBT persons in Latin America. For the first time, English speaking audiences will have access to commentary on decisions of national and international courts concerning rights of women and LGBT individuals in Latin America.

The cases and narratives presented in this volume expose the complexity of legal developments on gender and sexuality in Latin America. This book advances understanding of the rationales used in Latin American judgments concerning identity rights. It exposes the reasoning of judges that at the same time restrict and advance the exercise of rights by women and LGBT persons. It reveals a multifaceted legal reality where these individuals enjoy protections not yet achieved in other parts of the world, but, at the same time, shows how judicial reasoning has restricted their rights in much harsher ways than what is experienced in other regions.

The book explores the interplay between national and international law by analyzing decisions made by international bodies and courts such as the Inter-American Court of Human Rights. The Inter-American Court has been especially effective in strengthening the rights of women and LGBT individuals in the region with groundbreaking decisions that have recognized the right to be free from gender-based violence and the right to non-discrimination on the basis of sexual orientation.

This book is written by Latin American legal scholars with expertise on a broad range of legal issues: Citizenship by Cristina Motta, Family by Isabel Cristina Jaramillo, Health by Lidia Casas, Property by Helena Alviar, Violence by Julieta Lemaitre, Diverse Sexualities by Juan Marco Vaggione, and Violence based on Prejudice by Maria Mercedes Gomes. The chapters help to close the gap between the scholarship on gender and sexuality available in English and in Spanish. Gender and Sexuality in Latin America: Cases and Decisions will facilitate collaboration between scholars and activists from the global north and the global south who are interested in exploring the effectiveness of judicial reasoning in advancing the equality of all individuals, irrespective of their gender or sexual orientation. 



\section{Acknowledgements}

Special thanks from the editors to:

Diana Hortsch, Director of the Law School Initiative for the Center for Reproductive Rights, who has been instrumental to complete this project. Without the support of Diana, and of the Center for Reproductive Rights, New York, this book would have not been possible.

Luisa Cabal, Vice President of Programs at the Center for Reproductive Rights for her vision and leadership within the ALAS Network.

Cora Sueldo for translating the book from Spanish and Michelle Mora for her valuable work reviewing and editing the translated work.

Juny Montoya for reviewing all chapters in their original versions and writing many of the questions that make this book a teaching tool for law schools.

The Ford Foundation, the International Programme on Reproductive and Sexual Health Law of the University of Toronto and American University Washington College of Law for supporting the work of the ALAS network and funding the original version of the book in Spanish.

All members of the ALAS Network who have contributed directly or indirectly to the work presented in this book. This is a collaborative work beyond the authors and editors.

Professor Tony Varona for his support and vision in pushing for this book to be available to an English speaking audience; Professors Ann Shalleck, Rebecca Cook, and Dean Claudio Grossman for supporting the work of the ALAS Network from its inception.

Neil Olivier, Diana Nijenhuijzen, and their colleagues from Springer for supporting this project and making it possible.

Juan Tokatlian, Alejandra Tokatlian, Gonzalo Flores, Alonso and Amanda Flores-Saez for their constant support. They make our projects possible, and our lives better. 



\section{Biographies}

Cristina Motta holds a degree in Political Science from the University of Paris II, an LLM from Harvard Law School and a Licenciatura en Derecho from the University of Los Andes in Colombia. She has been law professor at the University of los Andes in Bogotá and San Andrés in Buenos Aires. She is an independent consultant.

Macarena Sáez holds an LLM from Yale Law School and a Licenciatura en Derecho from the University of Chile Law School. She is a Fellow in International Legal Studies and the Faculty Director of the Impact Litigation Project at American University Washington College of Law where she teaches in the areas of Family Law and Comparative Law.

Isabel Cristina Jaramillo holds an SJD and an LLM from Harvard Law School. She obtained her Licenciatura en Derecho from the University of Los Andes Law School in Colombia. Currently, she is an Associate Professor at the University of Los Andes Law School where she teaches Family Law and focuses on Critical Legal Theory, the Evolution of Family, and Feminist Jurisprudence.

Lidia Casas holds a BA in Urban Development from Saskatchewan University in Canada, an LLM from the University of Toronto and a Licenciatura en Derecho from Diego Portales University Law School in Chile. She is a Law Professor at Diego Portales University Law School where she concentrates on Sexual and Reproductive Rights.

Helena Alviar is the Dean of the University of Los Andes Law School in Colombia. She holds an SJD and an LLM from Harvard Law School and a Licenciatura en Derecho from the University of Los Andes Law School in Colombia. Among other topics, Dean Alviar's research focuses on Law and Economics, Gender and the Law and Legal Theory.

Julieta Lemaitre holds a master's in Religion and Gender from New York University, an SJD from Harvard Law School and a Licenciatura en Derecho from the University of Los Andes Law School in Colombia. Currently, she is an Assistant Professor at the University of Los Andes Law School. Among other topics, Julieta's 
research focuses on Social Movements and the Law, Violence and Sociology of Law, Domestic Violence, and Sexual and Reproductive Rights.

Julieta Di Corleto holds an LLM from Harvard Law School and a Licenciatura en Derecho from the University of Buenos Aires in Argentina. In addition to her work in the Public Defender's Office in Argentina, Julieta teaches Law at the University of Buenos Aires Law School and the University of Palermo Law School.

Juan Marco Vaggione holds a master's and a doctorate degree in Sociology from the New School for Social Research in New York, and a Licenciatura en Derecho from the National University of Cordoba in Argentina. He currently teaches law at the National University of Cordoba. He specializes on Gender, Sexuality, and Secularism.

Maria Mercedes Gómez holds a master's in Gender Studies and Feminist Theory and a doctorate degree in Political Theory from the New School for Social Research in New York, and a Licenciatura en Filosofia from the Javeriana University in Colombia. She specializes in Philosophy and Criminal Law. Regional Program Coordinator for Latin America and the Caribbean Organization International Gay and Lesbian Human Rights Commission (IGLHRC), New York. 


\section{Contents}

1 Introduction ................................................................................

Cristina Motta and Macarena Sáez

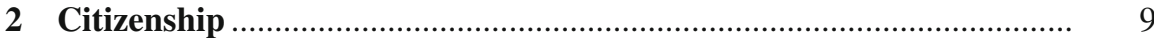

Cristina Motta

3 Family .................................................................................. 59

Isabel Cristina Jaramillo

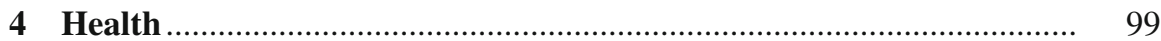

Lidia Casas

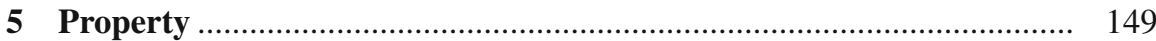

Helena Alviar

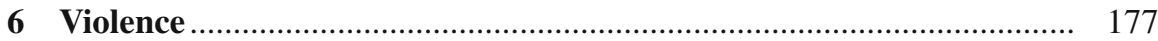

Julieta Lemaitre

$7 \quad$ Families Beyond Heteronormativity ..................................................... 233

Juan Marco Vaggione

8 Prejudice-Based Violence …….......................................................... 279

María Mercedes Gómez 